\title{
IMPLEMENTASI PEMBERIAN REWARD DALAM RANGKA MENINGKATKAN ETOS KERJA KEPALA DESA DI LAMPUNG TENGAH
}

\author{
Arohman $^{1)}$, Fatoni ${ }^{2)}$ \\ ${ }^{1}$ Fakultas Ekonomi dan Bisnis, Universitas Muhammadiyah Pringsewu \\ ${ }^{2}$ Fakultas Ekonomi dan Bisnis, Universitas Muhammadiyah Pringsewu \\ Email:arohman@umpri.ac.id \\ Email : fatoni@umpri.ac.id
}

\begin{abstract}
Abstrak
Pemberian reward sangat efektif untuk meningkatkan kinerja seseorang. Selain itu pemberian reward juga dapat menumbuhkan motivasi dan prestasi kenerja. Tujuan dari pemberian reward adalah untuk menumbuhkan dan meningkatkatkan hasil kinerja yang lebih berkualitas dan perilaku positif dalam melaksanakan pekerjaan yang dipercayakan oleh atasan. Bentuk reward dapat berupa finansial maupun non finansial. Jika reward merupakan reinforcement yang positif, maka didalam pemberian reward harus benar-benar di implementasikan oleh setiap intansi baik pemerintah atau swasta. Pada dasarnya reward sangat dibutuhkan dalam memotivasi seseorang termasuk dalam memotivasi para Kepala desa atau pekon di Kabupaten Lampung Tengah dalam meningkatkan kinerjanya. Pemberian reward merupakan upaya manajemen sumber daya manusia dari pimpinan terhadap kinerja dan produktivitas yang telah ditunjukkan oleh bawahannya.
\end{abstract}

Kata kunci: reward dan etos kerja.

\section{PENDAHULUAN}

Setiap organisasi harus terus menerus berkembang baik secara kuantitatif maupun kualitatif. Kepala desa merupakan pemerintahan desa sebagai kepala terendah pemerintah Kabupaten Lampung Tengah yang merupakan ujung tombak pemerintahan yang banyak berhubungan dengan masyarakatnya, diharapkan dapat turut berperan aktif didalam mensukseskan pembangunan didaerah, karena keberhasilan pembangunan ditingkat desa maupun keberhasilan pelaksanaan pemerintahan desa merupakan salah satu indikasi dari suksesnya pelaksanaan kebijakan otonomi daerah. Untuk itu, setiap kepala desa sebagai manajer di desanya tersebut harus memperhatikan hubungan setiap unit atau elemen agar dapat bersinergi dalam mencapai visi dan misi di desa atau daerah yang diharapkan. Hubungan dan sinergi antar elemen di desa dapat dibangun dengan komunikasi. 
Komunikasi dalam sebuah organisasi akan tampak jelas interaksinya antara atasan dan bawahan dalam setiap penyampaian pesan atau informasi yang terjadi dalam organisasi. Penghargaan merupakan suatu bentuk komunikasi yang dilakukan oleh atasan kepada bawahan dalam memotivasi Kepala Desa untuk lebih giat lagi dalam bekerja (Gibson dkk., 2011: 110). Didalam konteks desa, adanya implementasi komunikasi efektif melalui pemberian reward dapat menjadi motivasi bagi Kepala desa untuk bekerja secara produktif.

Produktivitas kerja dibangun dengan meningkatnya kepuasan para Kepala desa, sehingga diharapkan etos kerja mereka juga meningkat. Jika suatu komunikasi terjalin secara efektif dan motivasi kerja juga meningkat, maka akan mendapatkan suatu hasil Kepala Desa yang kompeten dan dapat membantu mereka dalam memperoleh kepuasan kerja, sehingga Kepala Desa yang telah merasakan adanya kepuasan kerja yang tinggi mempunyai sikap positif terhadap pekerjaannya dan seseorang yang tidak puas dengan pekerjaannya mempunyai sikap negatif terhadap pekerjaannya tersebut (Robbins, 2012: 36).

Reward sebenarnya sudah cukup lama dikenal dalam dunia pemerintahan, namun selalu terjadi perbedaan pandangan, mana yang lebih diprioritaskan antara reward (penghargaan) atau punishment (hukuman). Didalam konsep manajemen Kepala desa, reward merupakan salah satu alat untuk meningkatkan kinerja para Kepala desa. Metode ini bisa mengasosiasikan perbuatan dan kelakuan dengan perasaan bahagia, senang, dan biasanya akan membuat mereka melakukan suatu perbuatan baik secara berulang-ulang.

Selain memotivasi, reward juga bertujuan agar seseorang menjadi giat dan usaha untuk memperbaiki dan meningkatkan prestasi yang telah dicapainya. Jika reward merupakan reinforcement yang positif maka menjadi alat motivasi. Pada dasarnya, pemberian reward sangat dibutuhkan dalam memotivasi seseorang termasuk dalam memotivasi para Kepala desa di Kabupaten Lampung Tengah dalam meningkatkan kinerjanya. Hal ini merupakan upaya manajemen sumber daya manusia dari pimpinan terhadap kinerja dan produktivitas yang telah ditunjukkan oleh bawahannya. 
Setiap institusi profit maupun non-profit akan selalu berusaha untuk meningkatkan kinerja Kepala Desa dengan harapan apa yang menjadi tujuan pemerintah akan tercapai, dalam hal ini pencapaian visi dan misi pemerintah Kabupaten. Berbagai cara akan ditempuh oleh intitusi, khususnya institusi pemerintah dalam meningkatkan kinerja tenaga perangkat desa. Pihak manajemen desa dalam hal ini adalah Kepala desa, berusaha memperhatikan kepuasan kerja Kepala Desa, misalnya dengan pemberian insentif atau tunjangan tambahan bagi Kepala Desa yang disiplin dalam kehadiran.

Untuk meningkatkan etos kerja yang efektif, maka desa dapat memperhatikan hal yang paling utama yakni pemenuhan kebutuhan pegawainya. Untuk memenuhi kebutuhannya, maka diperlukan adanya penghargaan atau imbalan sebagai bentuk motivasi yang diberikan pada Kepala Desa. Menurut Gibson (2011:149), reward juga bertujuan agar seseorang menjadi semakin giat dalam usaha memperbaiki atau meningkatkan prestasi yang telah dicapainya. Reward merupakan bentuk metode dalam memotivasi seseorang untuk melakukan kebaikan dan meningkatkan prestasinya. Selain motivasi, reward juga bertujuan agar seseorang menjadi giat lagi usahanya untuk memperbaiki atau meningkatkan prestasi yang telah dapat dicapainya.

Dari penjelasan diatas, penelitian ini memfokuskan diri pada implementasi reward yang diupayakan oleh pihak pemerintah Kabupaten terhadap etos kerja yang dicurigai menurun dengan indikasi banyaknya Kepala desa yang tidak melaksanakan kewajibannya sebagai abdi negara dan minimnya prestasi Desa. Tujuannya adalah dengan adanya reward yang tinggi diharapkan etos kerja Kepala desa dapat ditingkatkan kembali demi pencapaian visi dan misi pemerintah kabupaten Lampung Tengah yang sudah ditetapkan.

\section{METODE PENELITIAN}

Desain penelitian adalah rencana dari struktur penelitian yang mengarahkan proses dan hasil penelitian sedapat mungkin menjadi valid, obyektif, efisien dan efektif (Jogianto, 2014). Desain penelitian ini menggunakan metode survey. Pengambilan data dengan metode survey sangat bergantung pada kemauan, kejujuran, dan kondisi Kepala Desa. Penelitian ini dilakukan untuk menjelaskan 
pengaruh antar variabel melalui pengujian hipotesis berdasarkan data yang diperoleh dari Kepala Desa. Jenis penelitian ini adalah penelitian kuantitatif dengan menggunakan metode deskriptif.

Popoulasi dalam penelitian ini adalah para Kepala desa di Kabupaten Lampung Tengah. Adapun sampel dari penelitian ini adalah 301 para kepala Desa di Kabupaten Lampung Tengah. Teknik sampling dalam penelitian ini menggunakan teknik convenience sampling (pemilihan sampel berdasarkan kemudahan).

Metode pengumpulan data dalam penelitian ini adalah menggunakan kuesioner. Kuesioner adalah metode yang digunakan untuk pengumpulan data dengan cara memberi daftar pertanyaan tertutup dan terbuka kepada objek penelitian yang disusun secara tertulis. Alternative jawaban dari kuesioner disusun dengan menggunakan skala Likert (Summated Rating Scale). Dalam skala ini skor seseorang Kepala Desa diperoleh dengan menjumlahkan (dan kemudian mencari rata-ratanya) nilai seseorang dalam masing-masing pernyataan yang sudah dibuat. Analisis data sebagai pengujian hipotesis dalam penelitian ini menggunakan regresi linear sederhana, adapuan yang menjadi variabel terikat adalah etos kerja, sedangkan yang menjadi variabel bebas adalah pemberian reward. Model hubungan variabel dalam penelitian ini disusun dalam persamaan atau fungsi sebagai berikut:

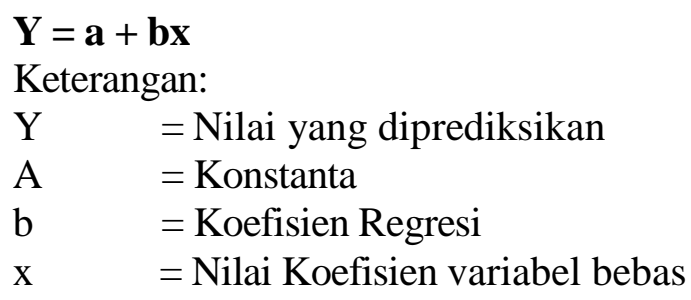

\section{HASIL DAN PEMBAHASAN}

Analisis deskriptif merupakan penjelasan dari data hasil penyebaran kuesioner tentang Pengaruh Pemberian Reward Terhadap Etos Kerja Kepala Desa di Lampung Tengah. Selain itu, digunakan untuk menganalisis data dengan cara mendeskripsikan atau menggambarkan data yang telah terkumpul dan dijelaskan dengan pendekatan teori. 
a. Pemberian reward Kepala Desa.

Salah satu tugas paling sulit yang dihadapi oleh berbagai macam organisasi yaitu tugas memotivasi karyawannya. Baik karyawan yang berada dalam jabatan manajerial maupun dalam jabatan non manajerial agar mereka melaksanakan pekerjaan mereka sesuai dengan prestasi kerja. Dengan adanya reward and punishment tertentu dalam bentuk rewardreward khusus (Special awards) atau promosi sebagai penunjang motivasi kerja mereka (Winardi, 2014: 345). Reward adalah imbalan, hadiah atau ganjaran. Dalam konsep manajemen, reward adalah salah satu alat untuk meningkatkan motivasi para pegawai. Organisasi memberi reward kepada karyawan untuk memotivasi kinerja mereka dan mendorong loyalitas. Reward organisasi memiliki sejumlah bentuk yang berbeda meliputi: uang (gaji, bonus, gaji insentif), penghargaan dan benefit (Fred Luthans, 2016: 153).

Human relations dalam aktivitas manajemen organisasi/lembaga adalah menciptakan suatu kerja sama antar karyawan dalam satu tim kerja, meningkatkan produktivitas, dan memperoleh kepuasan dalam bekerja. Dalam human relations tersebut kuncinya adalah bagaimana metode dalam berkomunikasi tersebut mampu menimbulkan "motivasi" yang berkaitan dengan kooperatif, kedisiplinan, etos kerja, produktivitas dan kepuasan bagi kedua belah pihak (khususnya dalam pemberian reward and punishment) (Ruslan, 2005: 83).

Sejumlah penelitian yang signifikan telah dilakukan mengenai apa yang menentukan kepuasan individu atas penghargaan. Lawle dalam John M. Ivancevich (2016: 226), meringkas lima kesimpulan berdasarkan literatur penelitian ilmiah tentang perilaku. Kesimpulan tersebut adalah:

a) Kepuasan terhadap suatu penghargaan merupakan fungsi dari berapa banyak yang diterima dan berapa banyak yang menurut individu seharusnya diterima.

b) Perasaan seseorang mengenai kepuasan dipengaruhi oleh perbandingan dengan apa yang terjadi dengan orang lain. 
c) Kepuasan dipengaruhi oleh seberapa puas karyawan dengan penghargaan intrinsik maupun penghargaan ekstrinsik.

d) Setiap orang memiliki perbedaan dalam hal penghargaan yang ia inginkan dan seberapa penting penghargaan tersebut baginya.

e) Beberapa jenis penghargaan ekstrinsik dianggap memuaskan karena jenis penghargaan ini menghasilkan penghargaan lain.

Pengaruh positif terhadap kepuasan karyawan akan menyebabkan para karyawan bekerja lebih giat dan dengan sendirinya akan berpengaruh pada tujuan yang akan dicapai oleh perusahaan yang bersangkutan. Metode ini bisa mengasosiasikan perbuatan dan kelakuan seseorang dengan perasaan bahagia dan biasanya akan membuat mereka melakukan suatu perbuatan yang baik secara berulang-ulang. Selain itu motivasi penghargaan juga bertujuan agar seseorang menjadi giat lagi usahanya untuk memperbaiki atau meningkatkan prestasi yang telah dicapai.

Untuk mengetahui distribusi frekuensi variabel pemberian reward pada kepala desa di Lampung Tengah, peneliti menyusun kuesioner berdasarkan indikator pemberian reward pada kepala desa di Lampung Tengah. Masing-masing indikator tersebut diwakili oleh item pernyataan dan telah disebarkan kepada 301 desa di Lampung Tengah dan selanjutnya dibuat kelas interval dengan kategori rendah, sedang, dan tinggi sehingga mempermudah dalam menginterpretasikan hasil tanggapan kepala desa mengenai pemberian reward.

\section{Tabel 1}

Tanggapan Pemberian Reward Kepala Desa di Lampung Tengah.

\begin{tabular}{cccc}
\hline Interval & F & \% & Kategori \\
\hline $20-46$ & 0 & $0 \%$ & Rendah \\
$47-73$ & 112 & $37,2 \%$ & Sedang \\
$74-100$ & 189 & $62,8 \%$ & Tinggi \\
Jumlah & 301 & $100 \%$ & \\
\hline
\end{tabular}

Sumber: Data hasil pengolahan 
Hasil penghitungan di atas, menjelaskan bahwa Pemberian Reward pada kepala desa di Lampung Tengah yang paling dominan masuk dalam kategori tinggi. Hal tersebut terlihat dari frekuensi pernyataan pada variabel Pemberian Reward sebesar 37,2\% atau sebanyak 112 Kepala Desa menganggap Pemberian Reward kepala desa di Lampung Tengah adalah sedang dan 62,8\% atau 189 Kepala Desa menganggap pemberian reward pada kepala desa di Lampung Tengah kategori tinggi.

b. Deskripsi Etos Kerja Kepala Desa

Etos Kerja merupakan fondasi dari sukses yang sejati dan otentik. Pandangan ini dipengaruhi oleh kajiannya terhadap studi-studi sosiologi sejak zaman Max Weber di awal abad ke-20 dan penulisan-penulisan manajemen dua puluh tahun belakangan ini yang semuanya bermuara pada satu kesimpulan utama; bahwa keberhasilan diberbagai wilayah kehidupan ditentukan oleh perilaku manusia, terutama perilaku kerja. Sebagian orang menyebut perilaku kerja ini sebagai motivasi, kebiasaan (habit) dan budaya kerja.

Sinamo (2015) lebih memilih menggunakan istilah etos karena menemukan bahwa kata etos mengandung pengertian tidak saja sebagai perilaku khas dari sebuah organisasi atau komunitas tetapi juga mencakup motivasi yang menggerakkan mereka, karakteristik utama, spirit dasar, pikiran dasar, kode etik, kode moral, kode perilaku, sikap-sikap, aspirasiaspirasi, keyakinan-keyakinan, prinsip-prinsip, dan standar-standar. Anoraga (2012) memaparkan secara eksplisit beberapa sikap yang seharusnya mendasar bagi seseorang dalam memberi nilai pada kerja, yang disimpulkan sebagai berikut:

a) Bekerja adalah hakikat kehidupan manusia

b) Pekerjaan adalah suatu berkat Tuhan.

c) Pekerjaan merupakan sumber penghasilan yang halal dan tidak amoral

d) Pekerjaan merupakan kesempatan untuk mengembangkan diri dan berbakti

e) Pekerjaan merupakan sarana pelayanan dan perwujudan kasih. 
Dalam penulisannya, Akhmad Kusnan (2014) menyimpulkan pemahaman bahwa etos kerja menggambarkan suatu sikap, maka ia menggunakan lima indikator untuk mengukur etos kerja. Menurutnya etos kerja mencerminkan suatu sikap yang memiliki dua alternatif, positif dan negatif. Suatu individu atau kelompok masyarakat dapat dikatakan memiliki etos kerja yang tinggi, apabila menunjukkan tanda-tanda sebagai berikut:

(1). Mempunyai penilaian yang sangat positif terhadap hasil kerja manusia

(2). Menempatkan pandangan tentang kerja, sebagai suatu hal yang amat luhur bagi eksistensi manusia

(3). Kerja dirasakan sebagai aktivitas yang bermakna bagi kehidupan manusia

(4). Kerja dihayati sebagai suatu proses yang membutuhkan ketekunan dan sekaligus sarana yang penting dalam mewujudkan cita-cita

(5). Kerja dilakukan sebagai bentuk ibadah.

Sementara itu, menurut Aziz (2011:1), etos kerja dapat diukur dalam 3 dimensi antara lain sebagai berikut:

1) Kerja Keras

Kerja keras adalah bentuk usaha yang terarah dalam mendapatkan sebuah hasil dengan menggunakan energi sendiri sebagai input (modal kerja). Seorang pekerja keras memiliki stamina yang kuat, kedayagunaan, dan ketersediaan diri yang tinggi. Berikut adalah ciri-ciri pekerja keras: stamina diri, disiplin, kedayagunaan dan kesediaan diri.

2) Kerja Cerdas

Kerja cerdas adalah bentuk usaha terarah untuk mendapatkan sebuah hasil dengan menggunakan mesin kecerdasan sebagai daya ungkit prestasi kerja. Kecerdasan seseorang dalam bekerja terlihat dari kemampuannya memperbesar skala, profesionalitas, 
inisiatif dan kreativitas, mengefektifkan sistim, kerja sama dan sinergitas, dan membina tim kerjanya.

3) Kerja Ikhlas

Kerja ikhlas adalah bentuk usaha terarah dalam mendapatkan sebuah hasil dengan menggunakan kesucian hati sebagai manifestasi kemuliaan dirinya. Seorang pekerja ikhlas memiliki kapasitas yang besar dan kejernihan pandangan. Selain itu hidupnya yang penuh keberuntungan digunakan untuk memberi manfaat sebanyak mungkin. Berikut ini adalah ciri-ciri pekerja ikhlas: kejujuran, kejernihan pandangan, orientasi non profit dan kepentingan umum, banyak memberi manfaat, pelayanan.

Adapun yang menjadi faktor yang mempengaruhi etos kerja adalah sebagai berikut :

(1) Agama

Pada dasarnya agama merupakan suatu sistem nilai. Sistem nilai ini tentunya akan mempengaruhi atau menentukan pola hidup para penganutnya. Cara berpikir, bersikap dan bertindak seseorang pastilah diwarnai oleh ajaran agama yang dianutnya jika ia sungguh-sungguh dalam kehidupan beragama. Dengan demikian, kalau ajaran agama itu mengandung nilai-nilai yang dapat memacu pembangunan, jelaslah bahwa agama akan turut menentukan jalannya pembangunan atau modernisasi. Weber (2011) memperlihatkan bahwa etos berpikir rasional, berdisiplin tinggi, bekerja tekun sistematik, berorientasi sukses (material), tidak mengumbar kesenangan, namun hemat (asketik), serta menabung dan berinvestasi, yang akhirnya menjadi titik tolak berkembangnya kapitalisme di dunia modern. Menurut Rosmiani (2006) etos kerja terkait dengan sikap mental, tekad, disiplin dan semangat kerja. Sikap ini dibentuk oleh sistem orientasi nilai-nilai budaya, yang sebagian bersumber dari agama atau sistem kepercayaan/paham teologi tradisional. Ia 
menemukan etos kerja yang rendah secara tidak langsung dipengaruhi oleh rendahnya kualitas keagamaan dan orientasi nilai budaya yang konservatif turut menambah kokohnya tingkat etos kerja yang rendah itu.

(2) Budaya

Selain temuan Rosmiani (1996) di atas, Usman Pelly (dalam Rahimah, 1995) mengatakan bahwa sikap mental, tekad, disiplin dan semangat kerja masyarakat juga disebut sebagai etos budaya dan secara operasional, etos budaya ini juga disebut sebagai etos kerja. Kualitas ini ditentukan oleh sistem orientasi nilai budaya masyarakat yang bersangkutan. Masyarakat yang memiliki sistem nilai budaya maju akan memiliki etos kerja yang tinggi dan sebaliknya, masyarakat yang memiliki sistem nilai budaya yang konservatif akan memiliki etos kerja yang rendah, bahkan bisa sama sekali tidak memilikinya. Dengan demikian, semangat kerja sangat ditentukan oleh nilai-nilai budaya yang ada dan tumbuh pada masyarakat yang bersangkutan.

(3) Sosial Politik

Soewarso, dkk (2015 menemukan bahwa tinggi rendahnya etos kerja suatu masyarakat dipengaruhi oleh ada atau tidaknya struktur politik yang mendorong masyarakat untuk bekerja keras dan dapat menikmati hasil kerja keras mereka dengan penuh. Dorongan untuk mengatasi kemiskinan, kebodohan dan keterbelakangan hanya mungkin timbul, jika masyarakat secara keseluruhan memiliki orientasi kehidupan yang teracu ke masa depan yang lebih baik. Orientasi ke depan itu harus diikuti oleh penghargaan yang cukup kepada kompetisi dan pencapaian (achievement).

(4) Kondisi Lingkungan/Geografis

Suryawati (2011) juga menemukan adanya indikasi bahwa etos kerja dapat muncul dikarenakan faktor kondisi geografis. Lingkungan alam yang mendukung mempengaruhi manusia 
yang berada di dalamnya melakukan usaha untuk dapat mengelola dan mengambil manfaat, dan bahkan dapat mengundang pendatang untuk turut mencari penghidupan di lingkungan tersebut.

(5) Pendidikan

Etos Kerja tidak dapat dipisahkan dengan kualitas sumber daya manusia. Peningkatan sumber daya manusia akan membuat seseorang mempunyai etos kerja keras. Meningkatnya kualitas penduduk dapat tercapai apabila ada pendidikan yang merata dan bermutu, disertai dengan peningkatan dan perluasan pendidikan, keahlian dan keterampilan, sehingga semakin meningkat pula aktivitas dan produktivitas masyarakat sebagai pelaku ekonomi (Rahimah, dkk, 2011).

(6) Motivasi intrinsik individu

Anoraga (2010) mengatakan bahwa individu yang akan memiliki etos kerja yang tinggi adalah individu yang bermotivasi tinggi. Etos Kerja merupakan suatu pandangan dan sikap, yang tentunya didasari oleh nilai-nilai yang diyakini seseorang. Keyakinan inilah yang menjadi suatu motivasi kerja.

Untuk mengetahui distribusi frekuensi Etos Kerja Kepala Desa di Lampung Tengah, peneliti menyusun kuesioner berdasarkan indikator Etos Kerja Kepala Desa. Masing-masing indikator diwakili oleh item pernyataan dan telah disebarkan kepada 301 kepala desa di Lampung Tengah dan selanjutnya dibuat interval dalam menginterpretasikan hasil tanggapan tentang Etos Kerja Kepala Desa.

Tabel 2

Tanggapan Tentang Etos Kerja Kepala Desa

\begin{tabular}{cccc}
\hline Interval & F & \% & Kategori \\
\hline $20-46$ & 31 & $10,29 \%$ & Rendah \\
$47-73$ & 171 & $56,81 \%$ & Sedang \\
$74-100$ & 99 & $32,90 \%$ & Tinggi \\
Jumlah & 301 & $100 \%$ & \\
\hline
\end{tabular}


Hasil perhitungan di atas menjelaskan bahwa Etos Kerja Kepala Desa di Kabupaten Lampung Tengah yang paling dominan masuk dalam kategori sedang. Hal tersebut ini dapat terlihat dari frekuensi pernyataan sebesar 56,81\% atau sebanyak 171 kepala desa di kabupaten Lampung Tengah memiliki Etos Kerja adalah berkategori sedang dan 32,90\% atau 99 kepala desa di kabupaten Lampung Tengah memiliki Etos Kerja berkategori tinggi serta 10,29\% atau 31 memiliki etos kerja kepala desa di kabupaten Lampung Tengah dalam kategori rendah.

Reward atau penghargaan meliputi banyak dari perangsang yang disediakan oleh organisasi untuk karyawan sebagai bagian dari kontrak psikologis. Penghargaan juga memuaskan sejumlah kebutuhan yang berusaha untuk dipenuhi oleh karyawan melalui pilihan mereka atas perilaku terkait pekerjaan (Moorhead \& Griffin, 2013). Untuk melihat implementasi pemberian reward dalam rangka meningkatkan etos kerja kepala desa di lampung Tengah.

\section{Tabel 3}

\section{Koefisien Determinasi}

\begin{tabular}{lcccc}
\hline \multicolumn{4}{c}{ Model Summary $^{\mathbf{b}}$} \\
\hline Model & $\mathrm{R}$ & R Square & Adjusted R Square & Std. Error of the Estimate \\
1 & 0,337 & 0,114 & 0,066 & 2,84730 \\
a. Predictors: (Constant), Pemberian Reward & \\
b. Dependent Variable: Etos Kerja Kepala Desa & \\
\hline
\end{tabular}

Sumber: Data hasil SPSS

Hasil perhitungan regresi linear Sederhana didapat nilai $r$-square sebesar 0,114 sehingga dapat disimpulkan bahwa Etos kerja kepala Desa di Kabupaten Lampung Tengah mampu dijelaskan sebesar 11,4\% oleh pemberian reward yang dilakukan oleh Pemerintah Kabupaten Lampung Tengah. Dengan kata lain, Pemberian Reward memberikan kontribusi sebesar 11,4\% terhadap Etos Kerja Kepala Desa di Kabupaten Lampung Tengah. 


\section{KESIMPULAN}

Implementasi dalam pemberian reward yang di lakukan oleh pemerintah Kabupaten Lampung Tengah mampu meningkatkan etos kerja Kerja kepala Desa di Kabupaten Lampung Tengah, serta dengan pemberian reward tersebut dapat memotivasi dan meningkatkan hasil kinerja serta dedikasi dalam melaksanakan tugas yang dipercayakan kepadanya masing-masing pribadi. Pemberian reward diharapkan mampu meningkatkan kepuasan kerja kepala Desa di Kabupaten Lampung Tengah sehingga akhirnya dapat meningkatkan etos kerja mereka, sebagaiman tercermin dari diagram alur berikut:

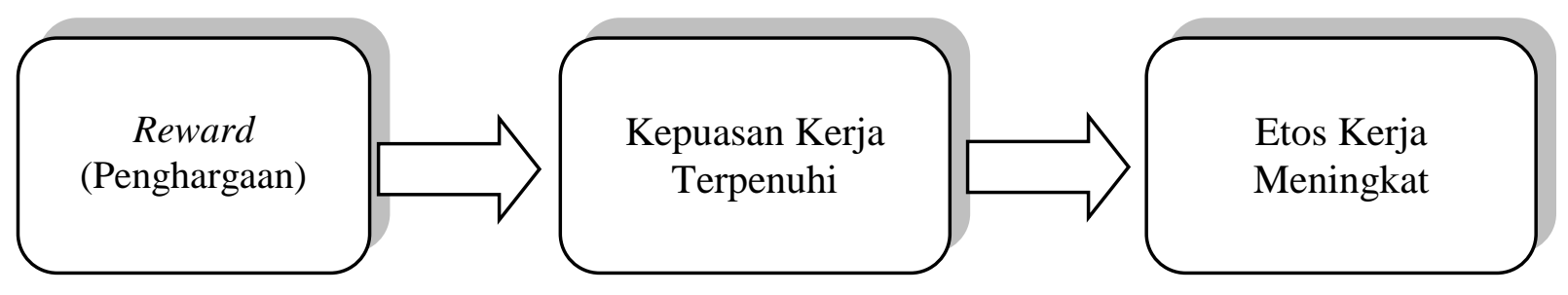

\section{DAFTAR REFERENSI}

Aziz. 2011. Komunikasi Antar Manusia. Jakarta: Profesional Books.

Gibson dkk. 2011. Organisasi, Perilaku, Struktur, Proses. Jakarta: Erlangga

Hassibuan, SP. Malayu. 2011. Manajemen Sumber Daya Manusia. Jakarta: BPFE.

Ivancevich, John M dkk. 2016. Perilaku dan Manajemen Organisasi. Jakarta: Erlangga

Kartono, Kartini. 1998. Pemimpin dan Kepemimpinan Dalam Organisasi. Jakarta: Raja Grafindo Persada.

Kreitner, Robert and Angelo Kinicki. 2005. Perilaku Organisasi (Orgaizational Behavior). Jakarta: Salemba Empat.

Luthans, Fred. 2016. Perilaku Organisasi Edisi Sepuluh. Yogyakarta: Andi.

Muhammad, Arni. 2001. Komunikasi Organisasi. Jakarta: Bumi Aksara.

Robbins, Stephen P. 2012. Prinsip-PrinsipPerilakuOrganisasi.Jakarta: Erlangga

Ruslan, Rosady. 2005. Manajemen Public Relations dan Media Komunikasi. Jakarta: Raja Grafindo

Sevilla, Consuelo G dkk. 1993. Pengantar Metode Penelitian. Jakarta: Universitas Indonesia (UI Press) 
ISSN Cetak : :2087-0434

E-ISSN $\quad: 2599-0810$

Suwarno. 1985. Pengantar Ilmu Pendidikan, Surabaya: Usaha Baru.

Umar, Husein. 2005 Riset Sumber Daya Manusia Dalam Organisasi. Jakarta: PT. Gramedia Pustaka Utama.

Winardi. 2014. Manajemen Kinerja. Jakarta: Rajawali Pers.

Wiryanto, Widiasarana.2004. Pengantar Ilmu Komunikasi. Jakarta: Gramedia Indonesia. 